\title{
Is There an Informal Employment Penalty in Food Security? Evidence from Rural Vietnam
}

\author{
Loan $\mathrm{Vu}^{1} \cdot$ Anu Rammohan ${ }^{2}$ \\ Accepted: 21 October 2021 / Published online: 5 January 2022 \\ (c) European Association of Development Research and Training Institutes (EADI) 2022
}

\begin{abstract}
In this paper, we investigate the association between informal non-farm wage employment and household food security in rural Vietnam. The data for our analyses come from a nationally representative panel dataset of 1390 rural households from Vietnam Household Living Standards Survey. We conduct multivariate regression analysis using robust quantitative tools to show that informal employment is associated with a reduction in the consumption of nutritious foods. Our analysis also shows that informal employment reduces consumption of vegetables and fruits, using both the calorie- and expenditure-based shares of food groups.
\end{abstract}

Keywords Food security · Non-farm · Informal employment · Formal employment · Vietnam

\section{Résumé}

Dans cet article, nous étudions l'association entre l'emploi salarié informel non agricole et la sécurité alimentaire des ménages dans les zones rurales du Vietnam. Les données utilisées pour nos analyses proviennent d'un ensemble de données de panel, représentatif au niveau national, de 1390 ménages ruraux ayant participé à l'enquête sur le niveau de vie des ménages au Vietnam. Nous conduisons une analyse de régression multivariée à l'aide de solides outils quantitatifs pour démontrer que l'emploi informel est associé à une réduction de la consommation d'aliments nutritifs. Notre analyse montre également que l'emploi informel est associé à une consommation moindre de légumes et de fruits, que ce soit en termes de calories consommées et de dépenses financières pour chaque groupe d'aliments.

Anu Rammohan

anu.rammohan@uwa.edu.au

Loan $\mathrm{Vu}$

lili.loanvu@curtin.edu.au

1 Department of Economics, University of Western Australia, Perth, Australia

2 Bankwest Curtin Economics Centre, Curtin University, Perth, Australia 


\section{Introduction}

Recent data show that severe food insecurity has increased in Vietnam from $2.3 \%$ in 2015 to $6.4 \%$ in 2017 , and the incidence of stunting among children aged under five years has also increased from 23.3 to $24.6 \%$ (FAO et al. 2018). Food insecurity is also much worse in rural areas where two-thirds of the population lives, with stunting rates among rural children three times higher than among urban children (Do et al. 2018), and poorer weight and height growth compared to urban children (Nguyen et al. 2013a, b).

In Vietnam, rural livelihood transformation has been associated with an increase in non-farm employment, a major source of income for rural households. For example, the proportion of rural population involved in non-farm work has increased from 36 to $48 \%$ percent between 2002 to 2014 (Duong et al. 2020a, b). However, more than $50 \%$ of non-farm jobs are informal in nature, do not provide access to social safety nets, and are widespread across manufacturing, construction, trade and services in Vietnam (Cling et al. 2010a, b). The International Labour Organization's (ILO) definition of informal employment includes jobs without access to social security benefits, and these are found in both formal and informal sectors (ILO 2013).

Previous research has empirically shown that non-farm income improves food and nutrition security in developing countries such as India and Nigeria (Babatunde and Qaim 2010; Ojeleye et al. 2014; Rahman and Mishra 2019). Similarly, empirical evidence from Vietnam finds that non-farm employment is positively associated with improvements in per capita food expenditure, consumption of nutritious food, and dietary diversity in rural Vietnam (Bui and Hoang 2020; Duong et al. 2020a, b; Tran and Vu 2020). However, these studies from Vietnam combine non-farm wage employment and self-employment (Bui and Hoang 2020), include both farm and non-farm work in wage employment (Tran and Vu 2020) and do not differentiate between informal and formal activities (Bui and Hoang 2020; Duong et al. 2020a, b; Tran and Vu 2020). Their results may therefore be biased due to significant differences between informal unskilled jobs, formal professional jobs, and self-employment in large-scale household businesses.

Informal workers are more likely to be under-paid and have lower income and job security relative to their formal counterparts (Nordman et al. 2016). This may reduce their food expenditures and negatively affect their household's food security. Informal employment is typically seasonal, unstable, precarious and lacks social protection against income shocks (Amuedo-Dorantes 2004). This is likely to adversely affect household food security relative to those households with more secure formal type of employment. This aspect has not previously been studied in the food security literature. Similarly, the focus of the informal labour force literature from Vietnam has been on the formal-informal earnings gap (Cling et al. 2010a, b; Nguyen et al. 2013a, b; Duong et al. 2020a, b), little is known about the influence of two types of employment for household food security in Vietnam.

The aim of this paper is to empirically examine the links between non-farm wage employment and household food security in rural Vietnam, specifically 
informal wage employment. We focus on non-farm wage employment as it is the most prevalent form of non-farm livelihood among rural Vietnamese households (Duong et al. 2020a, b). In particular, we use a panel dataset of 1390 rural households from the nationally representative Vietnam Household Living Standards Survey conducted in 2010, 2012, and 2014 to explore if informal work is adversely associated with household food security ("informality penalty"). ${ }^{1}$ More specifically, we aim to address the following questions: (i) what is the influence of non-farm employment on household food security? (ii) is there any evidence of an informality penalty in food security in rural Vietnam?

To the best of our knowledge, this is the first empirical study using panel data to empirically examine the influence of informal non-farm wage employment on household food security in rural Vietnam. This issue is critical because non-farm employment is dominated by informal labour, and informal employment is associated with greater poverty and uncertainty, which may influence household food security. The Government of Vietnam (GoV) has sought to address the lack of social insurance among informal employees. ${ }^{2}$ Furthermore, the existing literature on informal employment has not sought to address the issue of food security. The focus of this literature has been on aspects such as employment, income and enterprises' revenue (Nazier and Ramadan 2015). Unlike previous studies on informal employment and informal enterprises from Vietnam, we focus on the influence of informal employment on household food security. The availability of a panel dataset allows us to observe changes in food security in response to changes in livelihood and minimise estimation bias caused by unobserved heterogeneity across households.

\section{Background}

Informal and formal non-farm wage employment can influence household food security through several channels. Firstly, household income from non-farm sources has become increasingly important, with households increasingly relying on purchased food (Pritchard et al. 2019; Rammohan et al. 2019). Higher household income improves food affordability, and can also facilitate capital accumulation and re-investment into agricultural production (Babatunde and Qaim 2010). Informal workers typically have lower household income compared to formal workers (Cling et al. 2010a, b; Bargain and Kwenda 2011).

Additionally, poverty has been found to influence food insecurity (Pritchard et al. 2013; Rammohan and Pritchard 2014) and household dietary diversity in India and Myanmar, respectively. In Vietnam, poor households have lower food expenditure,

\footnotetext{
1 The term "informality penalty" is borrowed from the findings of "informal wage penalty" observed in Brazil, Mexico and South Africa by Bargain and Kwenda (2011, 2014) who find that informal workers are likely to receive lower wage rate compared to their formal counterparts.

2 The GoV introduced the first Labour Code in 1994 and the Law on Social Insurance in 2006 regulating that employers are required to buy compulsory social insurance for all employees working under a labour contract of three months or longer (formal employment).
} 
smaller consumption of nutritious food and poorer dietary diversity relative to nonpoor households (Thang and Popkin 2004; Mishra and Ray 2009). Previous studies show that informal wage employment increases the likelihood of poverty (Sastry 2004; Devicienti et al. 2009). Households are more likely to be currently poor if they were engaged in informal employment in the previous year (Devicienti et al. 2009). However, these studies only focus on informal workers working in the informal sector, but do not take into account those working in the formal sector without social security who can also be classified as informal workers (Devicienti et al. 2009).

Furthermore, informal workers' food consumption may be heavily affected by idiosyncratic shocks given a lack of access to social protection (Jütting and Laiglesia 2009). For example, health shocks such as illness of household head are found to reduce total food consumption and amount of purchased food within households in rural Ethiopia (Asfaw and von Braun 2004). Similarly, a recent study on the influence of the COVID-19 pandemic in Kenya and Uganda finds that loss of income is associated with a worsening in consumption of nutritious food and dietary diversity (Kansiime et al. 2021).

In a study addressing non-farm employment in India and Vietnam, Imai et al. (2015) find that a household with at least one member involved in manual and unskilled non-farm work has higher consumption per capita compared to households without non-farm work. This study, nevertheless, does not clarify if the non-farm jobs are informal or formal. Hieu et al. (2014) and Imai et al. (2015) both employ data from the Vietnam Household Living Standards Survey to examine the influence of non-farm work and informal employment on household income and poverty, but they do not further address the relationship between informal non-farm employment and food security.

The ambiguous results on the role of informal employment on household income may be due to factors affecting employment choices, income and poverty status. For instance, unskilled and low-educated people who are more likely to be poorer, may be less competitive in the formal job market, and are involuntarily involved in informal low-income jobs (Devicienti et al. 2009). On the other hand, informal employment may be a voluntary choice for tax minimisation, legal regulations and to escape from inefficient social security systems in developing countries (Maloney 2004; Packard 2007) so does not affect income level and the likelihood of poverty (Nazier and Ramadan 2015). Given the complicated relationships between informal and formal employment, household income and poverty, it is challenging to explore whether there is an informality penalty in food security.

To the best of our knowledge there are only two existing studies that examine the role of informal work on food security, and both these studies use cross-section data and are in the African urban context. Blekking et al.'s (2020) study from Zambia finds that a higher share of household members involved in informal employment is associated with poorer food and nutrition security. This study defines an informal worker as the person earning the highest income within household, working casually in manual labour in the short-term. On the other hand, using data from the African Food Security Urban Network survey conducted in 9 African countries, Crush et al. (2012) find that households with at least one full-time wage worker are more likely to be food secure than those with casual workers. 
However, rural and urban areas are significantly different in terms of both food security dimensions (availability and accessibility) and household livelihoods (Blekking et al. 2020). Our study therefore fills the research gap by empirically analysing the links between food security and informal employment in a rural context using a rich panel dataset.

\section{Data and Methodology}

We use data from the nationally representative Vietnam Household Living Standards Survey (VHLSS). The surveys have been conducted every two years since 2002 by the General Statistics Office (GSO) of Vietnam with the World Bank' technical assistance (GSO 2014).

The survey collects self-reported information on household living conditions including livelihoods, income, expenditure, food consumption, assets, housing, living facilities and other socio-economic and demographic information. This dataset is unique in providing information on both informal employment and food consumption at the household level in Vietnam.

The samples of VHLSS from 2010 onwards were randomly derived from the 2009 Vietnam Population and Housing Census. In each wave, approximately half of the households in the previous wave were repeatedly surveyed, the sample was designed so that the overlapped sample was still representative at the regional level. We use data from three waves conducted in 2010, 2012, and 2014. There were approximately 9400 households in each wave with nearly two-thirds residing in rural areas. The sample for our empirical analysis includes those rural households who were surveyed in all the three years, and for whom data is available on all our variables of interest. Details on the sample-selection process is presented in Fig. 2 in the Appendix A. The final sample includes a panel dataset of 1390 households. Attrition problem may occur in the construction of panel data. However, the results from our robustness tests using the pooled sample of rural households who were surveyed in the three years are consistently in line with our main empirical results (Table 8 in the Appendix B).

\section{Dependent Variables}

Our main dependent variables include household-level measures of dietary diversity measured using expenditure and calorie consumption shares of six main food groups. Dietary diversity has been established as a reasonable and crucial indicator of household's food and nutrition security status (Hoddinott and Yohannes 2002).

\section{Expenditure- and Calorie-Based Shares of Food Groups}

The data provides self-reported information on household expenditures and quantity of food consumed from 54 food items that were purchased, exchanged or otherwise (such as self-produced, gifted, collected from forests, etc.) in the last 30 days. We 
classify the food items into six different groups including (i) cereals and starches, (ii) meat, fish and egg, (iii) vegetables and fruits, (iv) milk and dairy products, (v) oil, seasonings, beverages, and (vi) food away from home. This classification is based on the number of food items available in the dataset and following previous studies on food security from Vietnam (Thang and Popkin 2004; Duong et al. 2020a, b). This implies that the food groups (i)-(v) include all food items consumed at home, and the group (vi) includes only purchased meals.

Firstly, we calculate expenditure of each food group in Vietnam Dong (VND). There may be discrepancies in monetary values across geographical locations in different waves. To synchronise all the monetary values, we use Regional Consumer Price Index (RCPI) for data from the waves 2010 and 2012. As the RCPI was not available in 2014, we estimate RCPI in 2014 as an average of the indices in 2010 and 2012. Using the RCPI and inflation rates, we compute adjusted food expenditures with the baseline of Hanoi (the country's capital) in 2010.

Secondly, we compute calorie consumption which is a more accurate representative of household food consumption, and it is independent of price discrepancies among food items across geographical regions over time (Molini 2006). The calorie equivalence amount of each food item is calculated using a calorie conversion table constructed by Vietnam's National Institute of Nutrition (see Nguyen and Winters (2011) for the Table). In the dataset some food items named "others" cannot be directly converted to calories. To deal with this issue, we follow Nguyen and Winters (2011), and use the average price of one calorie of each food group that is equal to the total expenditure divided by the total equivalent calories of all food items in that group. For example, the equivalent amount of calories from "other vegetables" is equal to its expenditure divided by average price of one calorie from all types of vegetables.

Based on household food expenditures and calorie consumption, we identify shares of the six food groups in each household. Food expenditures and quantity are self-reported and may include food waste and foods for pets and animals which are different across households, thus total food expenditures may not represent accurately the households' real human food consumption. We tested the robustness of our results using adjusted expenditures of the six food groups as our dependent variables. Our analyses found that the main findings hold. These results are not reported here due to space considerations.

\section{Simpson Index of Dietary Diversity}

The most basic indicator to measure dietary diversity is the Household Dietary Diversity Score (HDDS) which is computed by simply counting the number of food groups consumed within a household over a period of time (Hoddinott and Yohannes 2002). The information on food consumption in the VLHSS data was collected for the 30 days prior to the interview, so consumption across food groups was high. The HDDS is also unable to capture the variations in food consumption among households who consumed the same food groups in different amounts. We therefore adopt the Simpson index to measure dietary diversity more comprehensively. 
The Simpson index was first created by Simpson (1949) to measure diversity and has been widely used to measure diversity in previous studies (Jones et al. 2014; Rajendran et al. 2017; Dedehouanou and McPeak 2020). The index was also employed to investigate food security in Vietnam (see Duong et al. 2020a, b; Nguyen and Winters 2011). The equation used to compute the index is:

$$
\text { Simpson index }(\mathrm{SI})=1-\sum_{i} w_{i}^{2}
$$

where $w_{i}$ is the share of food group $i$ based on expenditures or calorie consumption. We use Groups (i), (iii), (iv), (v), and (vi), and separate Group (ii) category of nutritious foods into three smaller groups that include meat, fish and egg (totally eight groups) to maximise the index's variation. In this index, each food group component is assigned a weight corresponding with its share in the total food consumption. Thus, it can capture the fact that food consumption within rural households in Vietnam is mainly starchy. For example, between two households consuming the same food groups including starchy foods, who consumes less starchy foods and more other nutritious foods would have a greater dietary diversity level. The index takes the minimum value of zero if the household consumes only one food group and takes the maximum value of 0.875 if the household consumes all the eight food groups equally (share of each group is 0.125 ). Higher values of the index indicate greater dietary diversity.

\section{Explanatory Variables}

Our main explanatory variables are measures of household members' involvement in informal and formal non-farm wage employment. Respondents were asked to report the employment status of all household members, and the job that each member spent the most time in the last 12 months. We classify all non-farm wage employment into two categories- informal (without social insurance) and formal (with social insurance). We do not include unpaid jobs in the informal employment category as we are unable to identify whether the unpaid jobs are with/without social insurance. In Vietnam, individuals on non-wage employment can still purchase voluntary social insurance, which means that we cannot classify all unpaid employees as informal workers. Furthermore, paid and unpaid jobs are significantly different in terms of activities and characteristics that may have different influence on poverty, income (Lanjouw et al. 2013; Imai et al. 2015), and food security.

A household is defined as being in informal/ formal non-farm wage employment if at least one member was employed in an informal/ formal paid job in the last 12 months. The number of households involved in the two types of wage employment for each of the three waves are shown in Fig. 1. Approximately 776 households were not involved in non-farm wage employment in 2010, of which 680 households were involved in agricultural production, and 56 households had non-farm self-employment. In other words, the omitted category of households who were not involved in non-farm wage employment were mainly reliant on agricultural production. Among those involved in non-farm wage employment in 2010, there were 432 


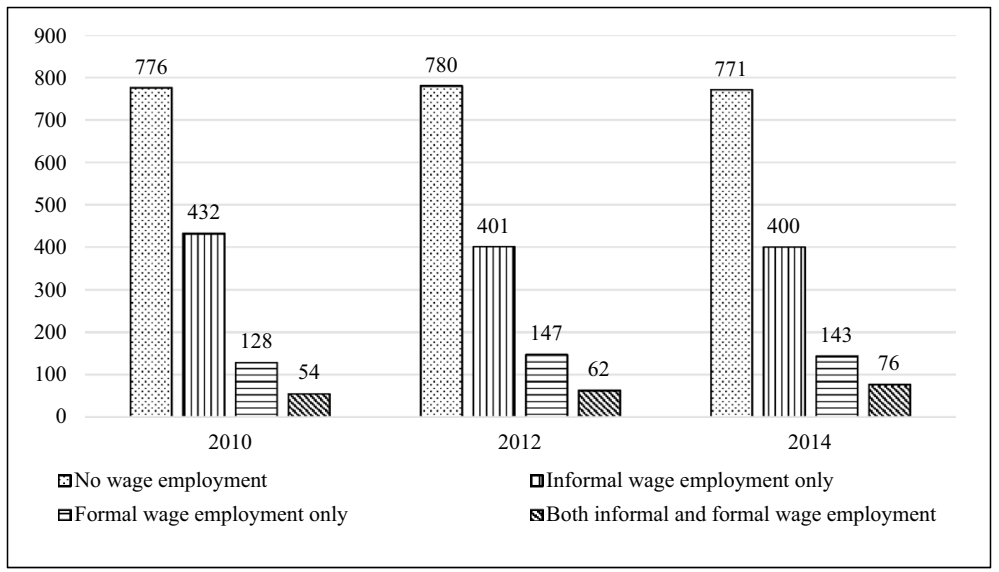

Fig. 1 Number of households involved in non-farm wage employment. Source: VHLSS, author's calculations

households involved in only informal employment and 128 households involved in only formal work, while 54 households had both types of employment. The figures changed slightly in 2012 and 2014, in that more households were involved in formal employment, and a combination of formal and informal employment (Fig. 1).

In Table 1 we present data disaggregated by household formal and informal nonfarm wage status. The table shows that households where members were predominantly in informal non-farm wage employment had lower per capita income per day compared to those where the majority of households were in formal non-farm wage employment. Among households with only informal non-farm wage employment, on average there were 1.513 informal workers per household, and the income per capita per day was approximately 65 thousand VND on average. ${ }^{3}$ Among households with only formal non-farm wage employment, there were on average 1.5 formal workers per household, and the income per capita per day was around 122,261 thousand VND on average, nearly double that of households with informal workers.

Our main dependent variables are the percentage shares of the six food groups. For our key measures of informal and formal non-farm wage employment to household income, we construct two variables: (i) Proportion of informal non-farm wage income to total household income, and (ii) Proportion of formal non-farm wage income to total household income. These two explanatory variables take values from 0 to 1 . Other control variables include household land ownership, household size, dependency ratio (ratio of the number of dependent members (below 15 and above 65 years) to the number of working age members in the 15-64 years) and characteristics of household head (sex, age and schooling years and ethnicity).

\footnotetext{
3 Monetary values in 2012 and 2014 are discounted to the 2010 baseline using national inflation rates. Price differences among geographical regions are addressed by using Regional Consumer Price Index (RCPI). Exchange rate on 31 December 2010: 1 USD = 19,505 VND.
} 


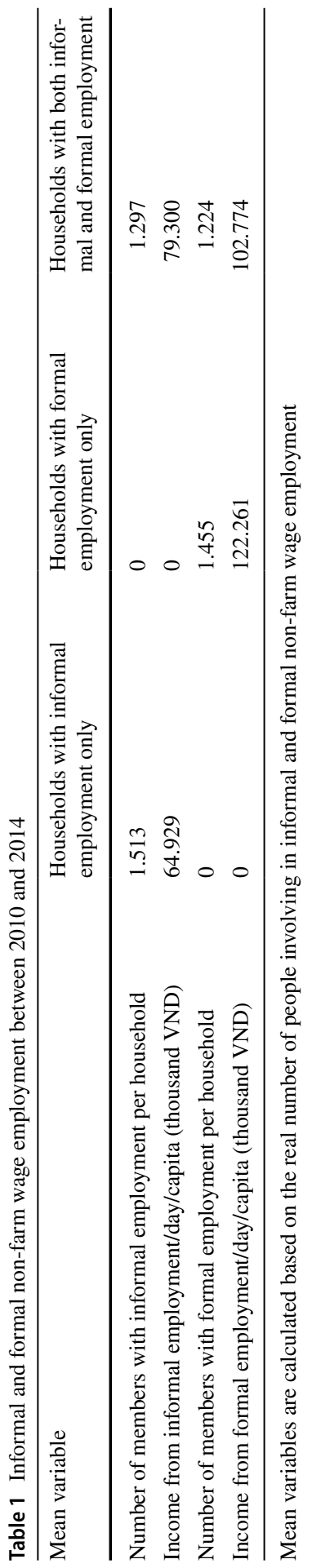




\section{Methodology}

\section{Pooled OLS}

We firstly employ pooled OLS regression models, using the general model given below:

$$
\text { Food security }_{h}=\alpha_{0}+\alpha_{1} \text { Informal }_{h}+\alpha_{2} \text { Formal }_{h}+\alpha_{3} X_{h}+r_{j}+\tau_{t}+\varepsilon
$$

where the subscript ' $h$ ' represents the $h^{\text {th }}$ household; dependent variable Foodsecurity $_{h}$ is measured by shares of main food groups, and the Simpson Index of dietary diversity. The main explanatory variables Informal $_{h}$ and Formal $_{h}$ are the proportion of informal and formal non-farm wage income to total household income, respectively. The coefficients $\alpha_{1}$ and $\alpha_{2}$ show the influence of households' involvement in informal and formal non-farm wage employment on household food security.

Variable $X_{h}$ is a vector of the household's socio-economic and demographic characteristics including household size, dependency ratio, agricultural land (area, square of area), characteristics of household head (gender, age, square of age, schooling years, and ethnicity), and household's poverty status. Variable $r_{j}$ refers to six geographical regions including Red River Delta region, Northern region, Central Coastal region, Central Highland region, Mekong River Delta region and the Southeast region. Variable $\tau_{t}$ indexes year fixed effects and $\varepsilon$ is the error term.

\section{Fixed-Effects Models}

To address potential bias due to the existence of unobserved factors, we include year dummies in an attempt to partly control for time-variant unobserved factors. To deal with the time-invariant unobserved heterogeneity across the surveyed households, we employ fixed-effects models. Our choice is motivated by the Hausman test results which show that $p<0.05$, we therefore reject the null hypothesis and use fixed-effects model in the main analysis. The Hausman test results are reported in the empirical results.

The fixed-effects model is given by:

$$
\text { Food security }_{i t}=\beta_{0}+\beta_{1} \text { Informal }_{i t}+\beta_{2} \text { Formal }_{i t}+\beta_{3} X_{i t}-+\tau_{t}+\omega_{i}+u_{i t}
$$

where the subscript " $i t$ " represents the $i$ th household in the $t$ th year, variable $X_{i t}$ is a vector of the household's socio-economic and demographic characteristics including household size, dependency ratio, agricultural land (area, square of area), characteristics of household head (gender, age, square of age, schooling years and ethnicity), and household's poverty status. We include household head's characteristics due to changes in household heads over the three years. The variable $\tau_{t}$ indexes year fixed effects and $u_{i t}$ is the error term. $\omega_{i}$ represents the time-invariant unobserved factors determining household's food security that is shown to be correlated with the other explanatory variables. 


\section{Fixed-Effects Instrumental Variables Estimation}

To minimise the bias in estimates caused by potential endogeneity, we use an instrumental variable approach. The instrumental variable needs to influence household informal and formal employment, but not be directly correlated with their food security.

Previous research finds that networks and information availability increase job opportunities and improve income (Kajisa 2007). This variable has been previously used to study how non-farm livelihoods and migration affect household well-being and food security in Vietnam (Nguyen and Winters 2011; Hoang et al. 2014; Bui and Hoang 2020). In our study, individuals with better networks have a higher likelihood of finding informal/formal employment. We use as instruments the two variables"Percentage of adults in informal non-farm wage employment" and "Percentage of adults in formal non-farm wage employment" at the commune (sub-district) level. In particular, we calculate the number of adults and informal/formal workers in each commune excluding the analysed household to ensure that the two instrumental variables vary across households in the commune. As expected, the instrumental variables are positively correlated with households' involvement in wage employment (Fig. 3 in the Appendix A).

The validity of using commune-level network variables as instruments may be influenced by the fact that commune characteristics may affect both our instruments and outcome variables. We test if there are correlations between the instruments and two commune characteristics significantly affecting food security including (i) Distance from commune centre to the nearest market $(\mathrm{km})$, and (ii) Distance from commune centre to the nearest city (hundred $\mathrm{km}$ ). ${ }^{4}$ The correlations are weak, ranging between -0.096 and -0.029 .

In the fixed-effects Instrumental variables estimation, Eq. (2) is used in the second-stage and the main dependent variables Informal $_{i t}$ and Formal $_{i t}$ are based on first-stage estimates. The first-stage equations may be formally written as:

$$
\text { Endogenous variable }_{i t}=\lambda_{0}+\lambda_{1} \text { Network_informal }_{i t}+\lambda_{2} \text { Network_formal }_{i t}++\lambda_{3} X_{i t}+\tau_{t}+\pi_{i t}
$$

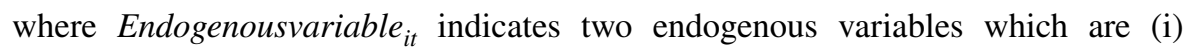
income from informal wage employment as a proportion of household income, and (ii) income from formal non-farm wage employment as a proportion of household income. Network_informal ${ }_{i t}$ refers to the percentage of adults at the commune level with informal non-farm wage jobs excluding the analysed household; and Network_formal ${ }_{i t}$ is the percentage of adults with formal non-farm wage jobs excluding the analysed household. The Variable $X_{i t}$ is a vector of the household's socio-economic and demographic characteristics including household size, dependency ratio, agricultural land (area, square of area), characteristics of household head (gender, age, square of age, schooling years and ethnicity), and household's poverty status. We include household head's characteristics since heads in several households were changed over the three years. The variable $\tau_{t}$ indexes year fixed effects and $\pi_{i t}$ is the error term.

\footnotetext{
${ }^{4}$ The information on distances from commune centre to the nearest market and city is only available for 3264 households in the panel sample.
} 
Table 2 Descriptive statistics

\begin{tabular}{|c|c|c|c|c|}
\hline Mean variables & Overall & 2010 & 2012 & 2014 \\
\hline \multicolumn{5}{|l|}{ Expenditure-based shares of food groups (\%) } \\
\hline Cereals and starches & 31.6 & 29.9 & 33.5 & 31.5 \\
\hline Meat, fish and egg & 28.8 & 30.4 & 28.4 & 27.7 \\
\hline Vegetables and fruits & 6.5 & 8.5 & 5.4 & 5.7 \\
\hline Milk and dairy products & 3.0 & 2.3 & 2.8 & 3.8 \\
\hline Oil, seasonings and beverages & 14.9 & 17.7 & 13.4 & 13.7 \\
\hline Food away from home & 15.1 & 11.1 & 16.5 & 17.6 \\
\hline \multicolumn{5}{|l|}{ Calorie-based shares of food groups (\%) } \\
\hline Cereals and starches & 59.5 & 57.9 & 61.2 & 59.3 \\
\hline Meat, fish and egg & 7.1 & 8.7 & 6.0 & 6.5 \\
\hline Vegetables and fruits & 2.7 & 3.8 & 2.1 & 2.1 \\
\hline Milk and dairy products & 0.7 & 0.7 & 0.7 & 0.8 \\
\hline Oil, seasonings and beverages & 14.9 & 17.7 & 13.4 & 13.7 \\
\hline Food away from home & - & - & - & - \\
\hline \multicolumn{5}{|l|}{ Indices of dietary diversity } \\
\hline Expenditure-based Simpson index & 0.725 & 0.744 & 0.715 & 0.717 \\
\hline Calorie-based Simpson index & 0.529 & 0.564 & 0.505 & 0.517 \\
\hline \multicolumn{5}{|l|}{ Households' involvement in non-farm wage employment } \\
\hline Proportion of informal wage income to total income & 0.175 & 0.176 & 0.173 & 0.175 \\
\hline Proportion of formal wage income to total income & 0.078 & 0.070 & 0.078 & 0.086 \\
\hline \multicolumn{5}{|l|}{ Households' characteristics } \\
\hline Household size & 3.971 & 4.037 & 3.992 & 3.883 \\
\hline Dependency ratio & 0.521 & 0.544 & 0.515 & 0.506 \\
\hline Agricultural land area per capita (hectare) & 1.860 & 1.718 & 1.926 & 1.936 \\
\hline Female household head & 0.211 & 0.200 & 0.214 & 0.218 \\
\hline Household head's age & 49.487 & 48.034 & 49.500 & 50.926 \\
\hline Household head's schooling years & 6.694 & 6.646 & 6.701 & 6.737 \\
\hline Ethnic minority household head & 0.237 & 0.239 & 0.237 & 0.235 \\
\hline Household is poor & 0.157 & 0.150 & 0.173 & 0.146 \\
\hline Observations & 4170 & 1390 & 1390 & 1390 \\
\hline
\end{tabular}

We do not calculate calorie-based share of food consumed away from home since there is no information on this group's food items being consumed

\section{Results}

\section{Descriptive Statistics}

Table 2 shows that on average, expenditure- and calorie- based Simpson index of dietary diversity was 0.73 and 0.53 , respectively. Compared to the possible maximum value of 0.825 (when the household consumes all the eight food groups equally with the share of each group is 0.125 ), the mean expenditure-based index was slightly lower, whilst the mean calorie-based index was significantly lower. 


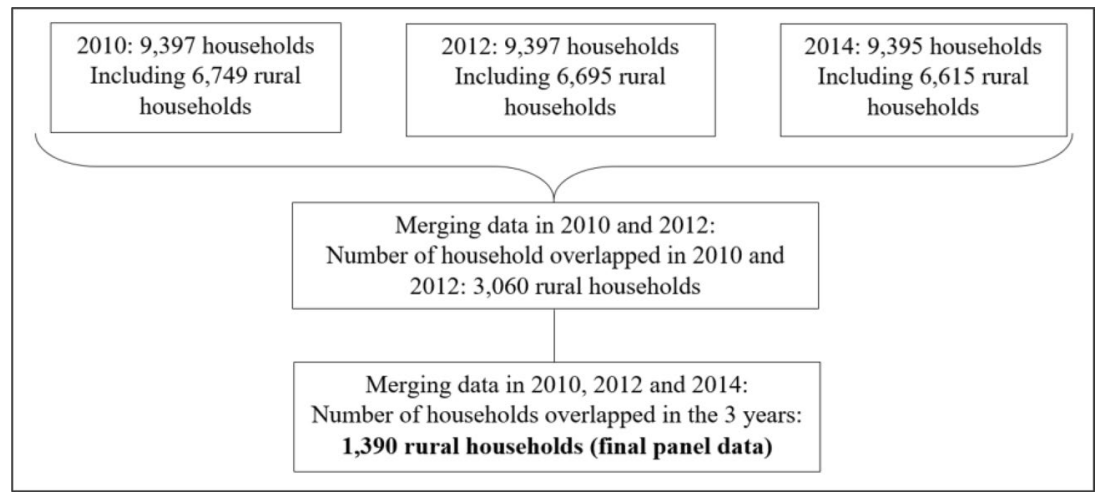

Fig. 2 Sample-selection process

Notably, the two indices fell over the three waves, indicating a downward trend in household dietary diversity in the survey period.

We further observe from Table 2 that cereals and starchy food made up a significant proportion of household food consumption, accounting for around $32 \%$ of total food expenditures, and nearly $60 \%$ of total calorie consumption. The protein-rich group of meat, fish and egg accounted for around $29 \%$ of food expenditures, but only made up $7 \%$ of total calorie consumption, suggesting that the high price of these nutritious food items acts as a constraint in rural areas. Vegetables and fruits accounted for nearly $7 \%$ of total food expenditures, and 3\% of calorie consumption. The households in the panel sample spent only $3 \%$ of their food expenditures on milk and dairy products. Notably, food away from home has increased over the three waves, from $11 \%$ of total household food expenditures in 2010 to nearly $18 \%$ in 2014. Since we do not observe what food was consumed away from home, we are unable to compute calorie-based shares. To calculate calorie-based shares of the other food groups, we assume that the calorie-based share of food away from home is equal to this food group's expenditure-based share.

From Table 2, we also observe that informal and formal wage employment accounted for around $18 \%$ and $8 \%$ of total household income on average, respectively. Over the three waves, the proportion of informal wage income remained the same, but the proportion of income from formal wage employment increased from 7 to $9 \%$.

In Table 3 we compare dietary diversity among households involved in informal non-farm wage employment only (Group 1) with those in formal non-farm wage employment only (Group 2). Households in Group 1 consumed lower shares of meat, fish, egg, vegetables, fruits, and milk, and also had lower Simpson indices of dietary diversity compared to households in Group 2. Notably, the share of cereals and starchy food rose slightly, whilst the proportion of protein and vitamin-rich foods such as meat, fish, egg, vegetables and fruits declined over time, both in terms of expenditures and calorie consumption. 


\section{Empirical Results}

The main results of our analysis are shown in Tables 4, 5 and 6. The estimates from expenditure-based shares of food groups are presented in Table 4, caloriebased shares of food groups are shown in Table 5, and estimates from the Simpson index of dietary diversity presented in Table 6. In each table, we present results from the pooled OLS in Panel A, fixed-effects models in Panel B, and fixed-effects Instrumental variables estimation in Panel C.

\section{Expenditure-Based Shares of Food Groups}

In Table 4 we find that higher formal employment is negatively associated with expenditure-based share of cereals and starches (Column 1). For example, using OLS estimates we show that if the proportion of formal income to a household's total income increases by 0.1 , expenditure-based share of cereals and starches in the household's food consumption reduces by nearly 1 percentage points (Column 1-Panel A). Results using fixed-effects models in Panel B and fixed-effects instrumental variables estimation in Panel $\mathrm{C}$ are similarly negative and statistically significant, although the size of the coefficient is smaller (Panel A, Column 1). Greater involvement in informal employment also reduces household consumption of starchy foods although the result is only statistically significant using OLS estimates (Column 1-Panel A).

Notably, we observe significantly negative associations between informal employment and shares of nutritious food items cooked at home. Column 2Panel A indicates that an increase of 0.1 in the proportion of informal income to total household income is associated with a reduction of nearly 0.2 percentage points in the shares of meat, fish and egg.

However, if the proportion of formal income increases by 0.1 , the share of milk and dairy products in the household food consumption rises by approximately 0.3 percentage points. In other words, a household fully dependent on formal employment has nearly 3 percentage points higher expenditure-based share of milk and dairy products, relative to those with no formal income (Column 4-Panel A).

A higher proportion of formal income increases consumption of food away from home significantly, and the influence of formal employment is nearly two-fold the influence of informal employment (Column 6). This finding holds across all models.

\section{Calorie-Based Shares of Food Groups}

The results from using calorie-based shares of food groups as dependent variables are presented in Table 5. We consistently observe that a higher involvement in informal employment is associated with a lower share of consumption of meat, fish and egg (Column 2), and share of vegetables and fruits consumption (Column 3). In particular, compared to households without income from informal 
Table 3 Food security among 2 groups of households' involvement in non-farm wage employment

\begin{tabular}{|c|c|c|c|c|c|}
\hline & \multicolumn{2}{|c|}{$\begin{array}{l}\text { Households with } \\
\text { informal wage } \\
\text { employment only } \\
\text { (Group 1) }\end{array}$} & \multicolumn{2}{|c|}{$\begin{array}{l}\text { Households with } \\
\text { formal wage employ- } \\
\text { ment only } \\
\text { (Group 2) }\end{array}$} & \multirow[t]{2}{*}{$(1)-(2)$} \\
\hline & Mean & $S D$ & Mean & $S D$ & \\
\hline \multicolumn{6}{|l|}{ Expenditure shares by food groups (\%) } \\
\hline Cereals and starches & 30.669 & 13.286 & 23.465 & 11.744 & $7.203 * * *$ \\
\hline Meat, fish and egg & 28.148 & 11.102 & 28.491 & 11.688 & -0.342 \\
\hline Vegetables and fruits & 6.210 & 4.030 & 5.906 & 3.890 & 0.304 \\
\hline Milk and dairy products & 2.822 & 5.979 & 5.330 & 8.214 & $-2.507 * * *$ \\
\hline Oil, seasonings and beverages & 14.579 & 7.069 & 13.399 & 6.589 & $1.180 * *$ \\
\hline Food away from home & 17.571 & 19.344 & 23.409 & 20.773 & $-5.838 * * *$ \\
\hline \multicolumn{6}{|l|}{ Calorie shares by food groups (\%) } \\
\hline Cereals and starches & 57.855 & 16.274 & 51.132 & 16.779 & $6.724 * * *$ \\
\hline Meat, fish and egg & 6.809 & 4.305 & 7.805 & 5.016 & $-0.996 * * *$ \\
\hline Vegetables and fruits & 2.508 & 2.418 & 2.877 & 3.315 & $-0.369 *$ \\
\hline Milk and dairy products & 0.678 & 1.549 & 1.379 & 2.331 & $-0.701 * * *$ \\
\hline Oil, seasonings and beverages & 14.579 & 7.069 & 13.399 & 6.589 & $1.180 * *$ \\
\hline Food away from home & - & - & - & - & - \\
\hline \multicolumn{6}{|l|}{ Indices of dietary diversity } \\
\hline Expenditure-based Simpson index & 0.730 & 0.098 & 0.739 & 0.097 & -0.009 \\
\hline Calorie-based Simpson index & 0.539 & 0.116 & 0.582 & 0.105 & $-0.043 * * *$ \\
\hline Observations & 1233 & & 418 & & 1651 \\
\hline
\end{tabular}

Italic indicates is self-evident

$T$-tests are used for the hypothesis that there is no difference between the two groups $* p<0.1, * * p<0.05$, $* * * p<0.01$

non-farm wage employment, a household with income fully derived from informal non-farm wage employment has nearly 2 percentage points lower share of meat, fish and egg. Notably, the calorie-based share of this food group was only around $7 \%$ on average (Table 2).

\section{Simpson Indices of Dietary Diversity}

Table 6 shows that having a higher proportion of formal income is positively and significantly associated with calorie-based Simpson index (Column 2-Panel A), whilst greater involvement in informal employment reduces expenditure-based index (Column 1-Panel B). For example, a household with all income from formal employment has a 0.06 point higher calorie-based index while a household with all income from informal employment has 0.02 point lower expenditure-based index, relative to households without formal and informal employment, respectively (Panel B). 


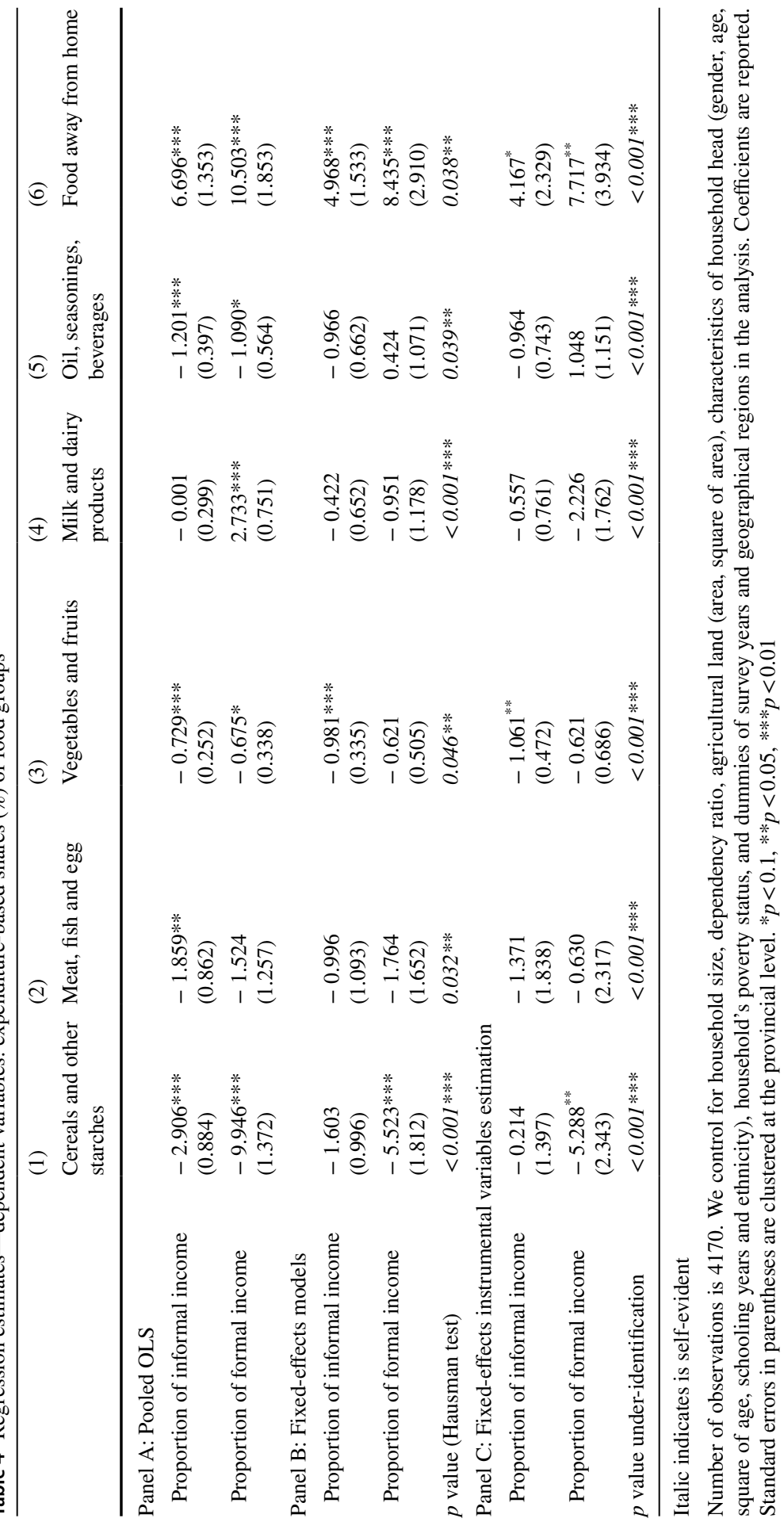


The higher consumption of food away from home among informal and formal non-farm wage employees observed in Tables 4, 5 and 6 may be due to the timeconsuming nature of food preparation. In addition, consumption of food away from home is positively affected by a rise in household income and employment of female household members and household head (Liu et al. 2015).

We investigate if expenditure-based share of food away from home is influenced by non-farm wage employment by females aged 15 years and above (Table 7, Column 1), whether household head has non-farm wage employment (Column 2), and non-farm wage income per day of the household head (Column 3). Table 7 shows that all these three factors are positively associated with share of food away from home which confirms our hypothesis.

\section{Estimates of Household Wellbeing}

To further investigate if there are differences in the influence of informal and formal non-farm wage employment on household well-being, we conduct further tests and these results are reported in Table 8 below. In Table 8, the dependent variables are income per capita, total expenditures per capita, food expenditures per capita, expenditures on durables per capita. The monetary values are converted to the baseline of the capital city in 2010 using the Regional Consumer Price Index (RCPI) and inflation rates, and we use log terms to make distributions of the dependent variables normal. In Columns 5-6, we use two binary dependent variables indicating households' access to sanitation and hygiene. The Hausman tests show that the fixedeffects are the most appropriate model for income per capita, expenditures per capita and food expenditures per capita, while the random effects are the most appropriate model for expenditures on durables. We use Probit models for the binary dependent variables (access to clean water and access to clean toilet). To address any possible correlation between the monetary dependent variables and income-related independent variables in Panel A, we alternatively use the proportion of informal and formal non-farm wage workers to number of adults aged 15 years and above as independent variables in Panel B.

Table 8 shows that while non-farm wage employment increases household income, the influence of formal employment is nearly double the influence of informal employment (Column 1). A higher proportion of formal income is positively associated with food expenditures whilst we do not observe any significantly positive influence of informal income (Column 3). Instead, a household with a higher proportion of informal income has lower expenditures per capita on purchasing durables (Column 4-Panel A), while formal employment is associated with higher durable expenditure (Column 4-Panel B), and better access to clean toilets (Column 6-Panel B).

The consistent results observed in Table 8 (Panels A and B) indicate that although both types of non-farm wage employment increase household income, formal employment improves household food expenditures and enhances living conditions, whilst informal employment is associated with a lower spending on durable goods. This is in line with previous results. In contrast to formal employment, informal 


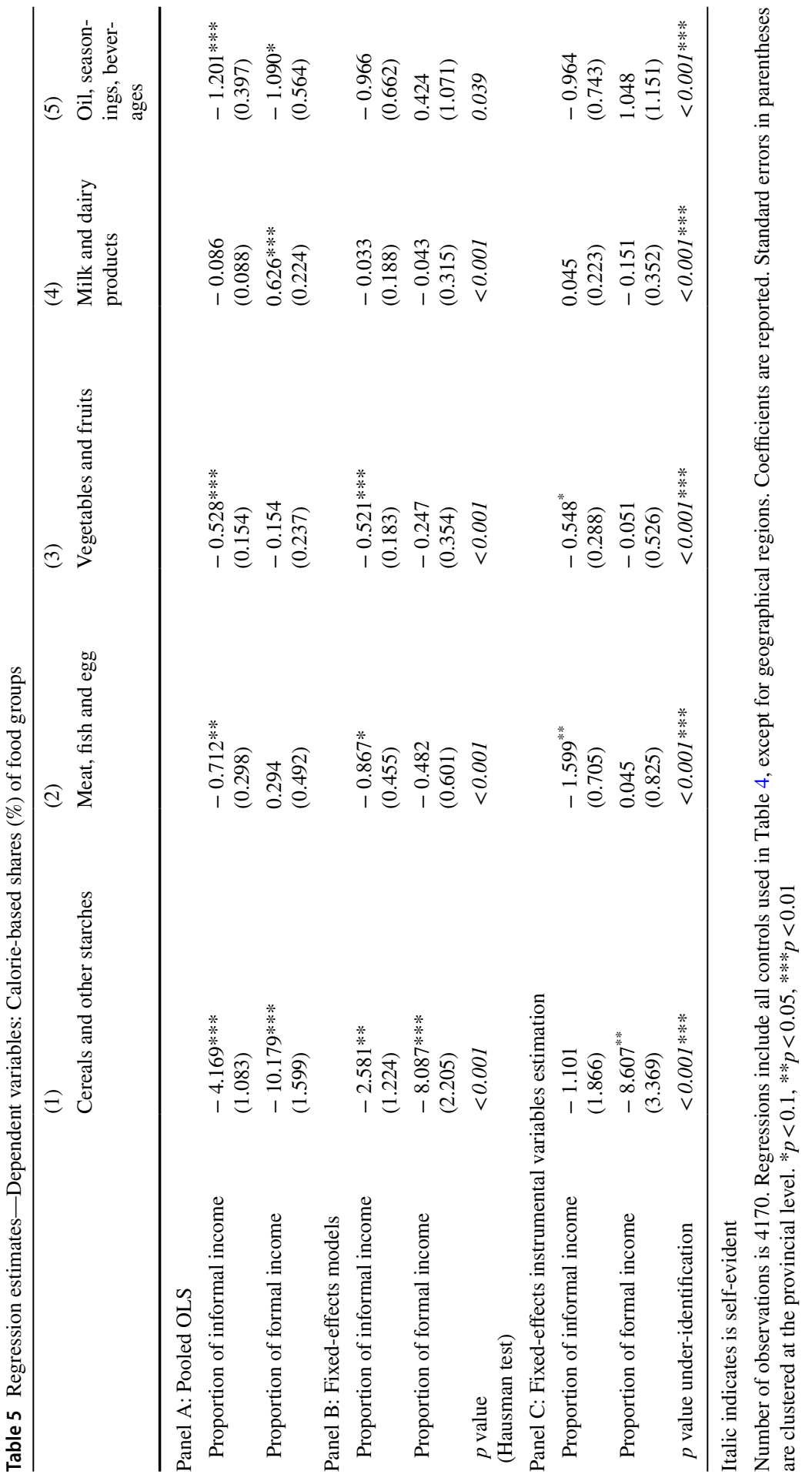


Table 6 Regression estimates_-Dependent variables: Indices of dietary diversity

(1)

(2)

Expenditure -based

Calorie -based

Simpson index

Simpson index

Panel A: Pooled OLS

Proportion of informal income

$\begin{array}{ll}-0.001 & 0.012 \\ (0.008) & (0.008) \\ 0.014 & 0.062 * * * \\ (0.011) & (0.013)\end{array}$

Panel B: Fixed-effects models

Proportion of informal income

$\begin{array}{ll}-0.019 * & -0.008 \\ (0.010) & (0.010)\end{array}$

Proportion of formal income

$-0.011$

0.028

(0.012)

(0.017)

$p$ value (Hausman test)

$<0.001$

$<0.001$

Panel C: Fixed-effects instrumental variables estimation

$\begin{array}{lll}\text { Proportion of informal income } & -0.006 & -0.000 \\ & (0.013) & (0.013) \\ \text { Proportion of formal income } & -0.008 & 0.032 \\ & (0.016) & (0.025) \\ p \text { value under-identification } & <0.001 * * * & <0.001 * * *\end{array}$

Italic indicates is self-evident

Number of observations is 4170. Regressions include all controls used in Table 4, except for geographical regions. Coefficients are reported. Standard errors in parentheses are clustered at the provincial level. $* p<0.1$, ** $p<0.05, * * * p<0.01$ 


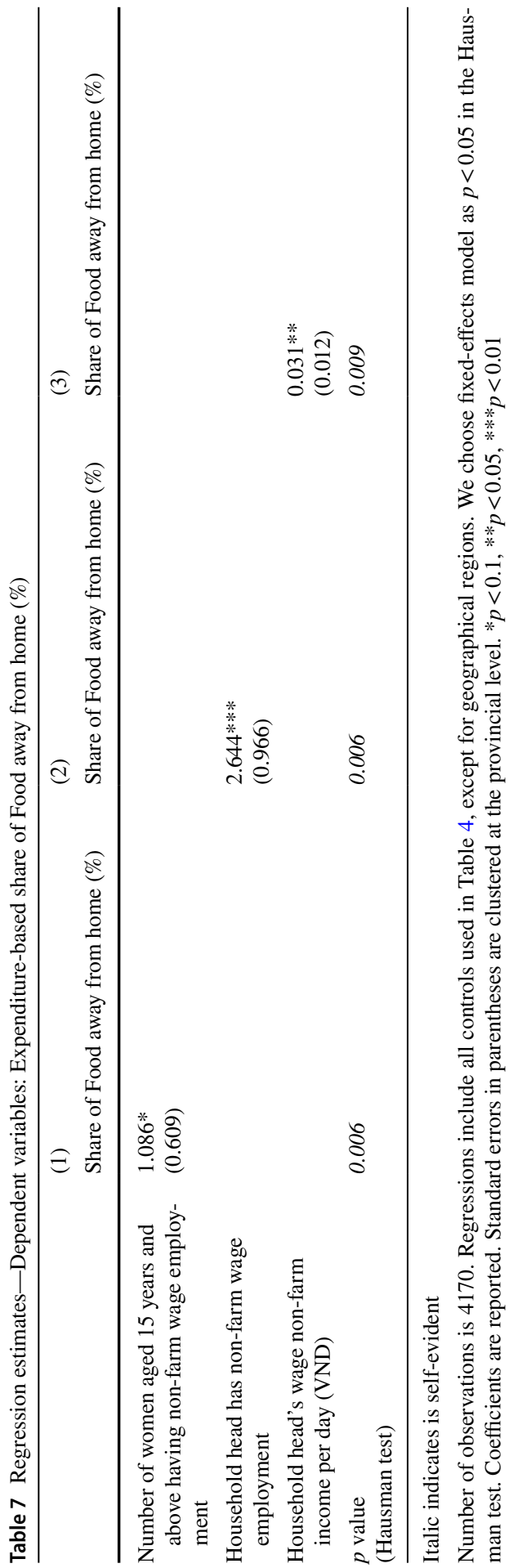

称 


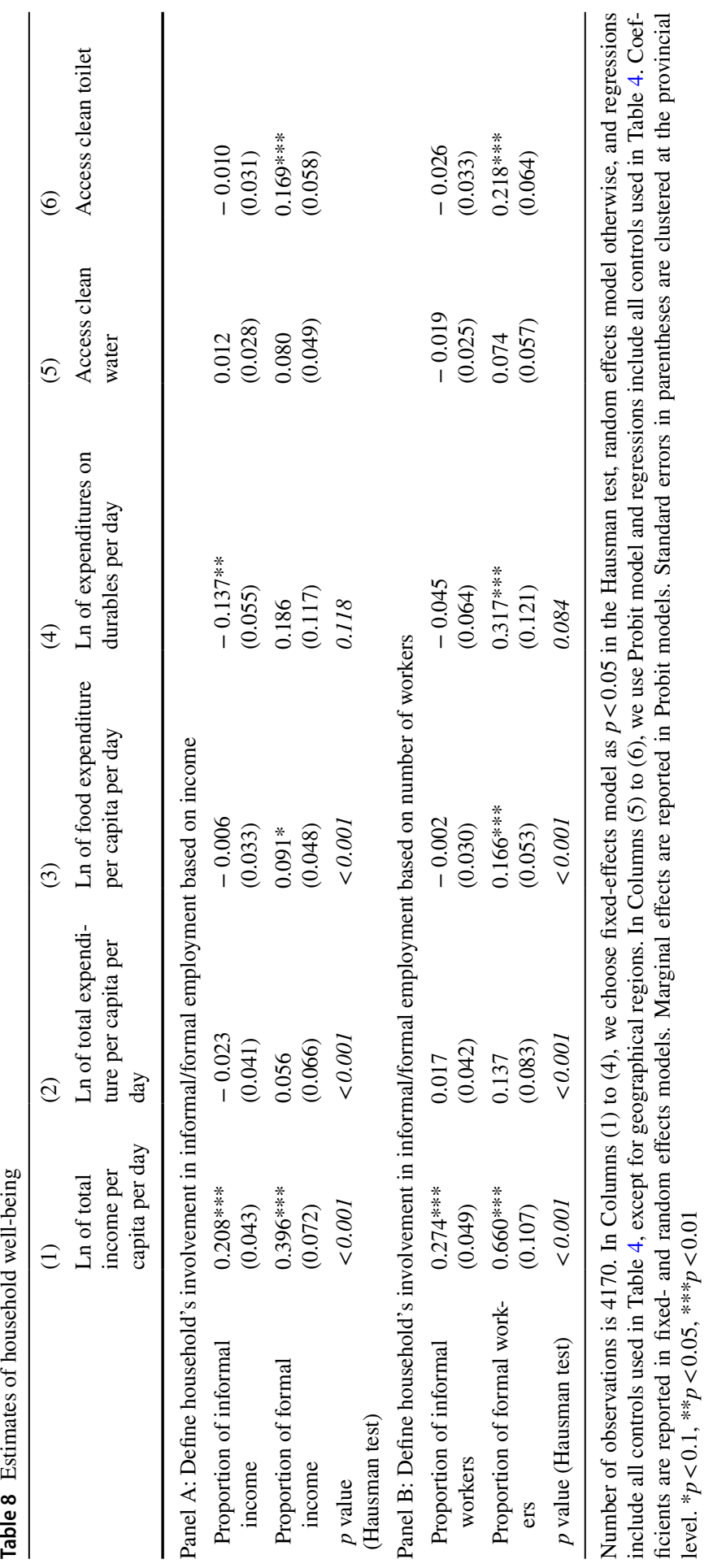


employment does not improve food expenditures, with households reducing home consumption of nutritious foods and expenditures on durables, while spending more on food consumed away from home.

\section{Conclusions}

Food insecurity in Vietnam is substantially worse in rural areas, where in recent years there has been a trend towards non-farm livelihoods. However, non-farm livelihoods are often dominated by informal employment, which is associated with greater job uncertainty, poorer working conditions and lower wages. This paper empirically examined the influence of informal non-farm wage employment on household food security in rural Vietnam, using panel data from the Vietnam Household Living Standards Survey (VHLSS).

Our analysis shows that informal employment is associated with a reduction in the consumption of vegetables and fruits, both under the expenditure-based and calorie-based shares of food groups. Secondly, informal employment also reduces households' consumption of nutritious food such as meat, fish and eggs, but this link is not observed for formal employment. While both types of non-farm wage employment are associated with a lower consumption of cereals and starches, there is an increase in the consumption of food consumed away from home, and the size of the coefficients are larger for formal employment. Meanwhile, the households involved in formal employment are able to increase their food expenditures, and also improve access to better sanitation and hygiene.

From a policy perspective, our study highlights the importance of formalization in Vietnam. There is a need to increase opportunities for formal employment to improve food security in rural areas. In addition, formality in rural employment may also improve household living conditions through a higher and more stable income compared to informal employment.

Our findings have important policy implications in addressing food and nutrition security in rural areas not only in Vietnam, but also in other developing countries where informal employment is widely prevalent. While there is ambiguity in the on the relationships between informal employment and poverty, household income, and other wellbeing indicators, limited empirical evidence on the influence of informal employment on food security. Our study therefore contributes to the literature on informality and food security, and provides empirical evidence to assist policy makers in addressing informality and food insecurity in developing countries.

\section{Appendix A}

See Fig 3. 


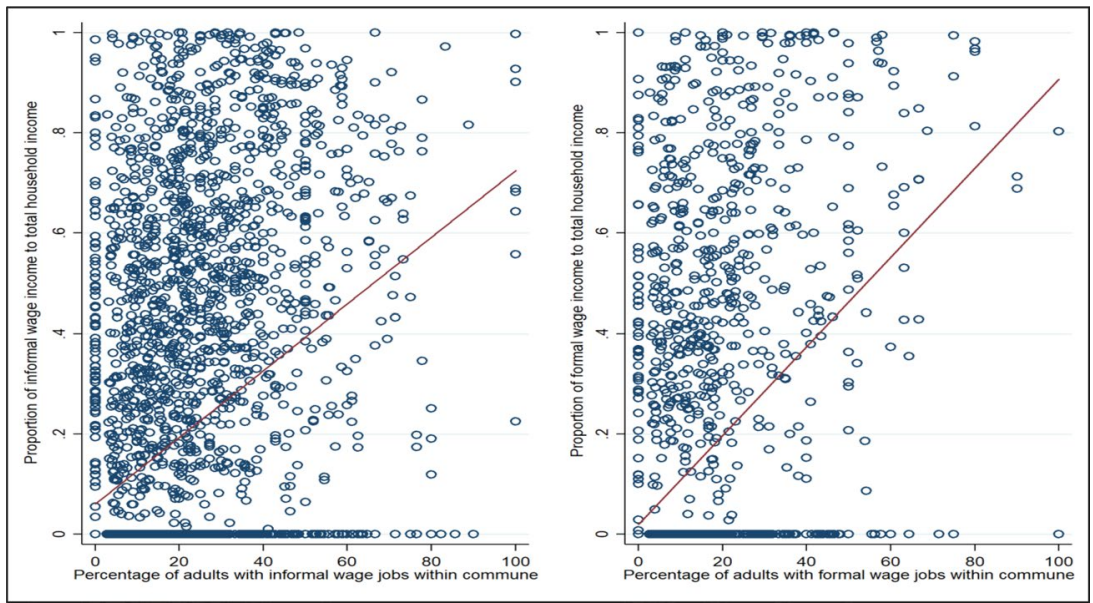

Fig. 3 Correlations between main explanatory variables and instrumental variables

\section{Declarations}

Conflict of interest On behalf of all authors, the corresponding author states that there is no conflict of interest.

\section{References}

Amuedo-Dorantes, C. 2004. Determinants and poverty implications of informal sector work in Chile. Economic Development and Cultural Change 52: 347-368.

Asfaw, A., and J. von Braun. 2004. Is consumption insured against illness? Evidence on vulnerability of households to health shocks in rural Ethiopia. Economic Development and Cultural Change 53 (1): 115-129.

Babatunde, R.O., and M. Qaim. 2010. Impact of off-farm income on food security and nutrition in Nigeria. Food Policy 35 (4): 303-311.

Bargain, O., and P. Kwenda. 2011. Earnings structures, informal employment, and self-employment: New evidence from Brazil, Mexico, and South Africa. Review of Income and Wealth 57: S100-S122.

Bargain, O., and P. Kwenda. 2014. The informal sector wage gap: New evidence using quantile estimations on panel data. Economic Development and Cultural Change 63 (1): 117-153.

Blekking, J., K. Waldman, C. Tuholske, and T. Evans. 2020. Formal/informal employment and urban food security in Sub-Saharan Africa. Applied Geography 114: 102131.

Bui, L., and H. Hoang. 2020. Non-farm employment, food poverty and vulnerability in rural Vietnam. Environment, Development and Sustainability 23: 7326-7357.

Cling, J., N.H. Chi, M. Razafindrakoto, and F. Roubaud. 2010a. How deep was the impact of the economic crisis in Vietnam? Washington, DC: World Bank.

Cling, J., M. Razafindrakoto, and F. Roubaud. 2010b. The informal economy in Viet Nam. Geneva: International Labour Organization.

Crush, J., B. Frayne, and W. Pendleton. 2012. The crisis of food insecurity in African cities. Journal of Hunger \& Environmental Nutrition 7 (2-3): 271-292.

Dedehouanou, S., and J. McPeak. 2020. Diversify more or less? Household income generation strategies and food security in rural Nigeria. The Journal of Development Studies 56 (3): 560-577. 
Devicienti, F., F. Groisman, and A. Poggi. 2009. Informality and poverty: Are these processes dynamically interrelated? Evidence from Argentina. https://ideas.repec.org/p/inq/inqwps/ecineq2009-146. html.

Do, M., L. Lissner, and H. Ascher. 2018. Overweight, stunting, and concurrent overweight and stunting observed over 3 years in Vietnamese children. Global Health Action 11 (1): 1517932.

Duong, P., P. Thanh, and T. Ancev. 2020. Impacts of off-farm employment on welfare, food security and poverty: Evidence from rural Vietnam. International Journal of Social Welfare, 1-13.

Duong, Q., H. Tran, T. Nguyen, and T. Doan. 2020b. Income gap in Vietnam using Bayesian quantile regression. Journal of Applied Economics and Business Research 10 (1): 11-21.

FAO, IFAD, UNICEF, WFP, and WHO. 2018. The state of Food security and Nutrition in the World 2018. Building climate resilience for food security and nutrition. Rome: FAO, IFAD, UNICEF, WFP, and WHO.

GSO. 2014. Result of the Vietnam Household Living Standards Survey 2014. Hanoi. http://www.gso.gov. vn/en/data-and-statistics/2019/03/result-of-the-vietnam-household-living-standards-survey-2014/.

Hieu, N., N. Giang, V. Ngoc, N. Duc, and T. Quan. 2014. Does the informal economy mitigate poverty and how does it work?: The case of Vietnam. https://idl-bnc-idrc.dspacedirect.org/handle/10625/ 54695.

Hoang, T., C. Pham, and M. Ulubasoglu. 2014. Non-farm activity, household expenditure, and poverty reduction in rural Vietnam: 2002-2008. World Development 64: 554-568.

Hoddinott, J., and Y. Yohannes. 2002. Dietary diversity as a food security indicator. Food Consumption and Nutrition Division Discussion Paper 136 (136): 2002.

ILO. 2013. The informal economy and decent work: A policy resource guide supporting transitions to formality. Geneva: ILO.

Imai, K., R. Gaiha, and G. Thapa. 2015. Does non-farm sector employment reduce rural poverty and vulnerability? Evidence from Vietnam and India. Journal of Asian Economics 36: 47-61.

Jones, A., A. Shrinivas, and R. Bezner-Kerr. 2014. Farm production diversity is associated with greater household dietary diversity in Malawi: Findings from nationally representative data. Food Policy 46: 1-12.

Jütting, J., and J. Laiglesia. 2009. Informal normal: Towards more and better jobs in developing countries. Paris: Development Centre Studies, OECD Publishing.

Kajisa, K. 2007. Personal networks and nonagricultural employment: The case of a farming village in the Philippines. Economic Development and Cultural Change 55 (5): 669-707.

Kansiime, M., J. Tambo, I. Mugambi, M. Bundi, A. Kara, and C. Owuor. 2021. COVID-19 implications on household income and food security in Kenya and Uganda: Findings from a rapid assessment. World Development 137: 105199.

Lanjouw, P., R. Murgai, and N. Stern. 2013. Non-farm diversification, poverty, economic mobility and income inequality: A case study in village India. Agricultural Economics 44 (4-5): 461-473.

Liu, H., T. Wahl, J. Seale, and J. Bai. 2015. Household composition, income, and food-away-from-home expenditure in urban China. Food Policy 51: 97-103.

Maloney, W.F. 2004. Informality revisited. World Development 32 (7): 1159-1178.

Mishra, V., and R. Ray. 2009. Dietary diversity, food security and undernourishment: The Vietnamese evidence. Asian Economic Journal 23 (2): 225-247.

Molini, V. 2006. Food security in Vietnam during the 1990s: The empirical evidence. Food Security: Indicators, Measurement, and the Impact of Trade Openness, Oxford, UK: Oxford University Press.

Nazier, H., and R. Ramadan. 2015. Informality and poverty: A causality dilemma with application to Egypt. Advances in Management \& Applied Economics 5 (4): 31-60.

Nguyen, H.C., C. Nordman, and F. Roubaud. 2013a. Who suffers the penalty?: A panel data analysis of earnings gaps in Vietnam. Journal of Development Studies 49 (12): 1694-1710.

Nguyen, H.T., B. Eriksson, M. Petzold, G. Bondjers, T. Tran, L. Nguyen, and H. Ascher. 2013b. Factors associated with physical growth of children during the first two years of life in rural and urban areas of Vietnam. BMC Pediatrics 13: 149.

Nguyen, M.C., and P. Winters. 2011. The impact of migration on food consumption patterns: The case of Vietnam. Food Policy 36 (1): 71-87.

Nordman, C., F. Rakotomanana, and F. Roubaud. 2016. Informal versus formal: A panel data analysis of earnings gaps in Madagascar. World Development 86: 1-17.

Ojeleye, O., M. Saleh, and S. Oyewole. 2014. Non-farm income and food security status of small scale farming households in Nigeria. Research Journal of Agriculture and Forestry Sciences 2 (12): 1-7. 
Packard, T. 2007. Do workers in Chile choose informal employment? A dynamic analysis of sector choice. World Bank Policy Research Working Paper No.4232.

Pritchard, B., A. Rammohan, M. Sekher, and S. Parasuraman. 2013. Feeding India: Livelihoods, entitlements and capabilities. Chapter 1: Introduction (pp. 1-18). Oxon, OX: Routledge.

Pritchard, B., A. Rammohan, and M. Vicol. 2019. The importance of non-farm livelihoods for household food security and dietary diversity in rural Myanmar. Journal of Rural Studies 67: 89-100.

Rahman, A., and S. Mishra. 2019. Does non-farm income affect food security? Evidence from India. The Journal of Development Studies 56 (6): 1190-1209.

Rajendran, S., V. Afari-Sefa, A. Shee, T. Bocher, M. Bekunda, I. Dominick, and P. Lukumay. 2017. Does crop diversity contribute to dietary diversity? Evidence from integration of vegetables into maizebased farming systems. Agriculture \& Food Security 6: 50.

Rammohan, A., and B. Pritchard. 2014. The role of landholding as a determinant of food and nutrition insecurity in rural Myanmar. World Development 64: 597-608.

Rammohan, A., B. Pritchard, and M. Dibley. 2019. Home gardens as a predictor of enhanced dietary diversity and food security in rural Myanmar. BMC Public Health 19 (1): 1145.

Sastry, N. 2004. Estimating informal employment and poverty in India. Discussion Paper Series No 7 , UNDP, Delhi.

Simpson, E. 1949. Measurement of diversity. Nature 163: 668.

Thang, N., and B. Popkin. 2004. Patterns of food consumption in Vietnam: Effects on socioeconomic groups during an era of economic growth. European Journal of Clinical Nutrition 58: 145-153.

Tran, T., and H. Vu. 2020. The pro-poor impact of non-crop livelihood activities in rural Vietnam: A panel data quantile regression analysis. Economic Analysis and Policy 68: 348-362.

Publisher's Note Springer Nature remains neutral with regard to jurisdictional claims in published maps and institutional affiliations. 